\title{
Responsivitas Pelayanan Publik Dinas Perhubungan Kota Malang terhadap Tingginya Tingkat Pengaduan Masyarakat
}

\section{The Responsiveness of Public Service Department of Transportation Malang City to The High Level of Public Complaints}

\author{
Hendra Hafid Risalbi ${ }^{1}$, Yaqub Cikusin ${ }^{2}$, Hayat $^{3}$ \\ ${ }^{1,2,3}$ Fakultas Ilmu Administrasi Negara, Fakultas Ilmu Administrasi, Universitas Islam Malang \\ Email: hendra.risalbi@gmail.com
}

Diterima: 31 Maret 2021

Direvisi:25 Juni 2021

Disetujui: 29 Juni 2021

DOI: 10.35967/njip.v20i1.135

\begin{abstract}
Abstrak: Responsivitas merupakan bentuk kepekaan dan kemampuan dari pemerintah dalam menyelenggarakan pelayanan, termasuk dalam pemberian pelayanan terhadap pengaduan masyarakat yang dilakukan oleh Dinas Perhubungan Kota Malang. Artikel ini bertujuan untuk mengetahui Responsivitas Dinas Perhubungan Kota Malang terhadap tingginya tingkat pengaduan masyarakat dan faktor penghambatnya. Untuk mengetahuinya digunakan jenis penelitian deskriptif - kualitatif, dengan teknik pengumpulan data wawancara, observasi dan dokumentasi. Dalam artikel ini menunjukkan bahwa responsivitas Dinas Perhubungan Kota Malang cukup responsif, hal ini dibuktikan dengan adanya penurunan tingkat pengaduan masyarakat setiap bulan khususnya pada tahun 2020. Selain itu, responsivitas Dinas Perhubungan Kota Malang juga dapat dilihat dari indikator kualitas pelayanannya, yaitu: (1) Tangible atau bukti fisik, (2) Reliability atau keandalan, (3) Responsiveness atau daya tanggap, (4) Assurance atau jaminan, dan (5) Empathy atau empati. Namun, pada implementasi pelayanan tersebut terdapat hambatan yakni banyaknya masyarakat yang belum paham tentang prosedur laporan pengaduan, adanya pengaduan yang tidak sesuai dengan fakta di lapangan, adanya masyarakat yang sering menuntut kecepatan penanganan dari instansi, dan sering terjadinya miss communication kepada masyarakat yang berdampak pada keterlambatan waktu penanganan.
\end{abstract}

Kata Kunci: Pelayanan Publik, Pengaduan Masyarakat, Pertanggungjawaban, Dinas Perhubungan Kota Malang

\begin{abstract}
Responsiveness is a form of sensitivity and ability of the government in providing services, including in the provision of services to public complaints made by the Malang City Transportation Service. This article aims to determine the responsiveness of the Malang City Transportation Service to the high level of public complaints and the inhibiting factors. To find out this type of research is descriptive - qualitative, with interview, observation, and documentation data collection techniques. This article shows that the responsiveness of the Malang City Transportation Service is quite responsive, this is evidenced by the decrease in the level of public complaints every month, especially in 2020. In addition, the responsiveness of the Malang City Transportation Service can also be seen from the service quality indicators, namely: (1) Tangible or physical evidence, (2) Reliability or reliability, (3) Responsiveness or responsiveness, (4) Assurance or assurance, and (5) Empathy or empathy. However, in the implementation of these services, there are obstacles, namely the number of people who do not understand the procedure for reporting complaints, the existence of complaints that are not in accordance with the facts on the ground, the existence of people who often demand speedy handling from agencies, and frequent miss communication to the public which has an impact on delays handling time.
\end{abstract}

Keywords: Public Service, Public Complaints, Responsibility, The Department of Transport of Malang City 
Nakhoda: Jurnal IImu Pemerintahan

Vol. 20 No. 01 Tahun 2021 Halaman 93-105

e-ISSN: 2656-5277 | p-ISSN: 1829-5827

\section{Pendahuluan}

Pada Undang-Undang Nomor 25 Pasal 1 Tahun 2009 dijelaskan bahwa pelayanan publik merupakan rangkaian kegiatan untuk memenuhi kebutuhan pelayanan yang sesuai dengan peraturan perundang-undangan bagi setiap warga negara dan penduduk atas barang, jasa, dan pelayanan administratif yang disediakan oleh penyelenggara publik. Menurut Sinambela menyatakan bahwa "Public" berasal dari Bahasa Inggris yang mengacu pada public, community, dan state (Suheli, Udan., Kahara, Fakhri., Kasmawati 2015). Sementara itu, menurut (Hayat, 2017) pelayanan publik dapat dipahami sebagai usaha sekelompok orang (organisasi) atau instansi untuk mempermudah mencapai tujuan dalam melayani masyarakat, maka dari itu dari inilah pelayanan publik lebih dikenal sebagai public service dalam ilmu administrasi publik. Sedangkan (Chowdhury, Soumitra. 2021) mengatakan pelayanan publik merupakan serangkaian aktivitas yang dilakukan oleh birokrasi publik untuk kebutuhan masyarakat.

Pelayanan publik merupakan hal yang harus dilakukan oleh pemerintah dan pelayanan publik menjadi hak yang harus didapatkan oleh masyarakat (Suherry et al, 2020). Maka dari itu, pemerintah memiliki kewajiban dan bertanggungjawab untuk memenuhi hak publik dalam bidang pelayanan publik yang prima dan profesional. Hal ini juga disebut dengan akuntabilitas pelayanan publik dikarenakan akuntabilitas merupakan suatu hal yang konkret dan harus ditentukan oleh hukum melalui seperangkat prosedur yang sangat spesifik mengenai masalah apa saja yang harus dipertanggungjawabkan (Sari et al. 2019). Namun, akuntabilitas adalah konsep yang lebih halus dan lebih luas daripada tanggung jawab laporan keuangan (Yurniwati., Rizaldi 2015). Dengan demikian, akuntabilitas menjadi salah satu indikator penting suatu pemerintahan terhadap kepercayaan publik (Kholmia, Masiyah. 2015).

Pelayanan merupakan hal yang sangat dibutuhkan dalam kehidupan, khususnya pelayanan yang berkecimpung pada bidang pelayanan pengaduan. Maka dari itu, peranan administrasi negara sangat dibutuhkan karena hal ini dapat dijadikan sebagai cerminan demokratis di negeri ini sehingga bisa jadi tolak ukur nantinya seberapa baik pelayanan yang diberikan kepada masyarakat (Ma and Ma 2011). Menurut Mursalim (2018) bahwa memang pengaduan merupakan suatu sumber informasi yang sangat dibutuhkan bagi publik dan ke depannya bisa digunakan sebagai tolak ukur evaluasi pelayanan yang belum tercapai selama ini kepada publik/stakeholder, sehingga perlu desain sistem baru dalam menangani keluhan ini agar bisa memperbaiki kualitas ke depannya. Sedangkan, menurut Peraturan Menteri Negara Pendayagunaan Aparatur Negara Nomor: PER/05/M.PAN/4/2009 tentang Pedoman Umum Penanganan Pengaduan bagi Instansi Pemerintah menjelaskan bahwa sebuah pengaduan merupakan bentuk pengawasan dari masyarakat yang selalu melihat atau mengevaluasi apa yang disampaikan oleh pemerintah baik itu lisan maupun tertulis yang di dalamnya berupa pikiran, saran, gagasan, keluhan, dan pengaduan yang bertujuan membangun bersama. Hal tersebut juga dijelaskan oleh (Ghazzawi, Amani., Alharbi 2019) bahwa keluhan pelanggan dapat digunakan sebagai ukuran yang akurat tentang seberapa sukses suatu layanan, terutama dengan transformasi teknologi informasi menjadi konsep dan ide. Maka dari hal tersebut, sektor publik perlu merancang penyampaian layanan yang menangani tugasnya dalam memberikan layanan kepada semua warga negara tanpa diskriminasi (Tangi, Luca. 2021).

Proses penanggungjawaban pengaduan membutuhkan waktu yang tidak sedikit untuk mencapai penanganan yang sesuai harapkan, akan tetapi pengaduan tetap menjadi suatu pekerjaan yang harus diperbaiki atau dilayani dengan banyak pertimbangan agar sesuai dengan apa yang diharapkan oleh pihak yang mengajukan pengaduan tersebut. Dalam proses pengaduan diperlukan laporan pendukung yang sesuai prosedur, hal ini bisa memperkuat proses pengajuan agar bisa segera dilaksanakan (Hayat n.d.). Hal ini sesuai dengan yang dikatakan (Prasetya 2013) dalam berbagai pengaduan tidak semua pengaduan dapat diproses dengan segera ada beberapa pertimbangan yang harus dipahami dari pengaduan yang diajukan kepada pihak substansi 
Nakhoda: Jurnal IImu Pemerintahan

Vol. 20 No. 01 Tahun 2021 Halaman 93-105

e-ISSN: 2656-5277 | p-ISSN: 1829-5827

tersebut karena menyangkut beberapa poin yaitu tanggung jawab dan pelaksanaan yang harus segera diproses. Sedangkan menurut (Larasati 2016) dalam penanganan pengaduan publik bisa disebut juga sebuah proses atau rangkaian yang di dalamnya meliputi observasi, monitoring, observasi, konfirmasi, klarifikasi dan yang akan dikaji lebih dalam pada pemeriksaan di mana bertujuan untuk mengungkap kebenaran pengaduan yang diajukan oleh pihak masyarakat. Pengaduan masyarakat merupakan bentuk dari Penerapan E-Government memberikan efisiensi dan kecepatan pengelolaan pada sistem administrasi pelaporan, serta transparansi proses yang terjadi dalam penyelenggaraan pemerintahan (Suryotrisongko, Hatma., Jayanto, Dedy Puji. 2017).

Berbicara mengenai tentang pelayanan publik dalam penanggungjawaban terhadap pengaduan masyarakat, peneliti memberikan perhatian besar pada responsivitas pelayanan publik Dinas Perhubungan Kota Malang. Responsivitas merupakan kemampuan birokrasi untuk mengenali kebutuhan masyarakat, menyusun agenda dan prioritas pelayanan, serta mengembangkan program-program pelayanan sesuai dengan kebutuhan dan aspirasi masyarakat Dinas Perhubungan Kota Malang merupakan Dinas Perhubungan yang memiliki tingkat kesibukan yang sangat padat (Rochmah n.d.). Adapun beberapa bidang atau bagian di dalam Dinas Perhubungan Kota Malang antara lain: bagian lalu lintas, bagian angkutan umum, bagian parkiran, dan lain sebagainya (Santoso and Suwitri 2018). Selain melayani Pemerintah Kota Malang dalam bertugas, Dinas Perhubungan juga sering dihadapi oleh banyaknya pengaduan dari masyarakat dalam hal lalu lintas, infrastruktur, sarana prasarana dan sebagainya. Pengaduan masyarakat dikelompokkan pada bidang lalu lintas, bidang angkutan dan bidang keparkiran yang total sebanyak 391 pengaduan. Hal ini sebagaimana disajikan pada Tabel 1.

Tabel 1. Jumlah Laporan Pengaduan Tahunan 2020

\begin{tabular}{cccccc}
\hline No. & Bulan & $\begin{array}{c}\text { Bidang Lalu } \\
\text { Lintas }\end{array}$ & $\begin{array}{c}\text { Bidang } \\
\text { Angkutan }\end{array}$ & $\begin{array}{c}\text { Bidang } \\
\text { Keparkiran }\end{array}$ & Jumlah \\
\hline 1 & Januari & 20 & 11 & 9 & 40 \\
2 & Februari & 14 & 23 & 10 & 47 \\
3 & Maret & 18 & 12 & 13 & 43 \\
4 & April & 5 & 16 & 4 & 24 \\
5 & Mei & 14 & 23 & 11 & 48 \\
6 & Juni & 16 & 8 & 17 & 41 \\
7 & Juli & 7 & 13 & 8 & 28 \\
8 & Agustus & 9 & 4 & 16 & 29 \\
9 & September & 5 & 8 & 7 & 20 \\
10 & Oktober & 13 & 2 & 9 & 24 \\
11 & November & 16 & 6 & 7 & 29 \\
12 & Desember & 8 & 7 & 3 & 18 \\
\hline
\end{tabular}

Sumber : Data Dinas Perhubungan Kota Malang Evaluasi Buku Besar, Data Diolah (2020)

Pengaduan yang sering terjadi adalah banyaknya masyarakat atau publik yang tidak puas terhadap pelayanan yang dilakukan oleh Pemerintah khususnya Dinas Perhubungan Kota Malang dan banyaknya masyarakat yang merasa dirugikan bila pelayanan yang di berikan oleh instansi tidak ada perubahan. Berdasarkan Tabel 1, mengindikasikan jika setiap bulan terdapat penurunan pengaduan yang signifikan dari bidang lalu lintas, angkutan. Hal ini menunjukkan bahwa responsivitas pelayanan publik Dinas Perhubungan Kota Malang terhadap tingginya tingkat 
Nakhoda: Jurnal IImu Pemerintahan

Vol. 20 No. 01 Tahun 2021 Halaman 93-105

e-ISSN: 2656-5277 | p-ISSN: 1829-5827

pengaduan masyarakat sudah cukup baik. Maka dari adanya fenomena tersebut, peneliti tertarik untuk meneliti lebih dalam tentang bagaimana penerapan pelayanan publik sebagai aparatur negara sepenuhnya beserta hambatan-hambatan yang dialami pada Dinas Perhubungan Kota Malang dalam penanggungjawaban merespons pengaduan yang diajukan oleh masyarakat.

\section{Metode}

Penelitian ini menggunakan pendekatan penelitian deskriptif-kualitatif. Menurut Bungin (Wulandari, Unde, and Fatima 2017) metode kualitatif deskriptif merupakan metode di mana peneliti berusaha merekonstruksi atau mendeskripsikan hasil wawancara secara mendalam terhadap sasaran yang akan diteliti atau objek penelitian. Adapun yang menjadi informan sebanyak 9 orang yakni dari Kepala Sub Bagian Kepegawaian dan Pelayanan dan 8 staf kesekretariatan lainya. Untuk mendapatkan data yang tepat, peneliti menggunakan beberapa teknik pengumpulan data yakni wawancara mendalam, dokumentasi dan mengumpulkan data beserta membuat kesimpulan (Yandra 2017). Kemudian data dianalisis menggunakan metode interaktif sebagaimana yang telah di kemukakan oleh Miles dan Huberman, bahwa kegiatan analisis terdiri dari tiga alur kegiatan yang terjadi secara bersamaan, yaitu reduksi data, dan penarikan kesimpulan atau verifikasi (Wulandari et al. 2017).

\section{Hasil dan Pembahasan}

1. Responsivitas Pelayanan Publik Dinas Perhubungan Kota Malang Terhadap Tingginya Tingkat Pengaduan Masyarakat

Responsivitas dimasukkan sebagai salah satu indikator kinerja karena responsivitas secara langsung menggambarkan kinerja dan kemampuan organisasi publik dalam menjalankan misi dan tujuannya, terutama untuk memenuhi kebutuhan masyarakat. Responsivitas yang rendah menunjukkan adanya ketidakselarasan antara pelayanan dan kebutuhan masyarakat, hal ini menunjukkan kegagalan organisasi dalam mewujudkan misi dan tujuan organisasi dalam mewujudkan tujuan organisasi (Tangilisan n.d.) Untuk mengetahui bagaimana responsivitas pelayanan publik Dinas Perhubungan Kota Malang terhadap tingginya tingkat pengaduan masyarakat dapat dilihat dari kualitas dan kuantitasnya sebagai berikut:

\section{a) Kualitas Pelayanan Publik Dinas Perhubungan Kota Malang Dalam Merespons Pengaduan Masyarakat}

Kualitas pelayanan publik adalah tingkatan keunggulan yang diharapkan dari layanan publik dan pengadilan atas tingkat keunggulan untuk memenuhi keinginan masyarakat (Asrida 2018). Selain itu, kinerja organisasi publik juga berpengaruh dalam menentukan kualitas pelayanan publik karena jika semakin rendah kinerja organisasi publik maka akan semakin buruk pula kualitas pelayanan yang akan diberikan. Terdapat beberapa indikator atau dimensi yang menjadi dasar pengukuran kualitas pelayanan publik, yakni bukti langsung (tangible), keandalan (reliability), daya tanggap (responsiveness), jaminan (assurance), dan empati (empathy) (Riyanda n.d.).

Dalam rangka menilai sejauh mana kualitas pelayanan publik yang diberikan oleh aparatur Negara, perlu adanya faktor/kriteria kualitas pelayanan publik untuk menunjukkan apakah suatu pelayanan publik yang diberikan dapat dikatakan baik atau buruk, berkualitas atau tidak. Kualitas pelayanan publik di Dinas Perhubungan Kota Malang dapat dinilai dari 5 dimensi yaitu :

1. Tangible atau bukti fisik, berdasarkan hasil penelitian yang dilakukan terkait dengan bukti fisik yakni fasilitas pendukung pelayanan di Dinas Perhubungan Kota Malang sudah memadai dan membantu proses pelaksanaan kepada masyarakat. 
2. Reliability atau keandalan, Dinas Perhubungan Kota Malang telah melakukan pelayanan kepada masyarakat dengan baik. Hal ini ditandai dengan pelayanan yang sesuai dengan SOP (Standar Operasional Prosedur). Selain itu, dari hasil penelitian didapatkan jika komunikasi yang digunakan oleh Dinas Perhubungan Kota Malang lebih mengarah pada standar pelayanan yang ramah dan bertanggung jawab atas berinteraksi dengan masyarakat yang datang untuk melaporkan pengaduan ke Dinas Perhubungan Kota Malang. Konteks komunikasi dalam pelaksanaan excellent service (pelayanan prima) pada Dinas Perhubungan Kota Malang menjadi suatu motivasi Dishub Kota Malang dalam melayani masyarakat/publik khususnya dalam berkomunikasi, sehingga para staf Dinas Perhubungan Kota Malang sudah terlatih dan sudah tertanam pada semua komitmen awal bergabung pada instansi tersebut sehingga tidak perlu melakukan adanya pelatihan dan pengawasan yang berlebih pada bidang pelayanan karena sudah tahu apa yang harus dilakukan standar pelayanan yang ada di Dinas Perhubungan Kota Malang ini.

3. Responsiveness atau daya tanggap, responsivitas pelayanan publik Dinas Perhubungan Kota Malang terhadap tingginya tingkat pengaduan masyarakat dinilai sudah ada peningkatan. Dengan kata lain bahwa Dinas Perhubungan Kota Malang dalam menyelenggarakan tugas pelayanannya memiliki responsivitas yang cukup tinggi terhadap kebutuhan pelayanan khususnya pelayanan administrasi laporan pengaduan yang diharapkan masyarakat. Selain itu, dalam hal pelayanan Dinas Perhubungan Kota Malang menerapkan atau memiliki dasar pelayanan yaitu excellent service (pelayanan prima) yang bertujuan untuk berkemampuan totalitas terhadap publik yang mengajukan pengaduan dan guna memberikan respons yang baik kepada publik. Hal ini juga ditekankan oleh Hayat dkk. (2018) yang menyatakan bahwa yang perlu digaris bawahi dalam kebutuhan masyarakat adalah perlu keprofesionalan dalam melakukan pelayanan publik yang di dalamnya telah ada pengaturan administrator yang gunanya untuk menumbuhkan pelayanan yang berkualitas bagi masyarakat sehingga bisa benar-benar memahami dan menyelesaikan kebutuhan masyarakat. Selain itu, menurut Lopez, Liz, dan Fontaine (2019) kinerja sektor publik sangat berpengaruh terhadap kualitas layanan yang diberikan kepada masyarakat Penilaian ini diperoleh melalui pernyataan-pernyataan informan dan pengamatan peneliti di lapangan, di mana dari segi kemampuan aparat mengenai bentuk pelayanan yang sesungguhnya dibutuhkan oleh masyarakat dirasa sudah cukup baik.

4. Assurance (jaminan), di mana Dinas Perhubungan Kota Malang memberikan jaminan kemudahan layanan dan jaminan keamanan kepada masyarakat yang mengajukan permohonan layanan Dinas Perhubungan Kota Malang, khususnya dalam hal pengaduan yang dilakukan oleh masyarakat.

5. Empathy (empati), Dinas Perhubungan Kota Malang telah memberikan pelayanan yang baik dan memuaskan. Hal ini tercapai karena pegawai yang melayani masyarakat memiliki sikap yang ramah dalam melayani masyarakat. Selain itu Dinas Perhubungan Kota Malang bersikap terbuka dam menerima permintaan, saran dan kritik yang diberikan oleh masyarakat.

Selain itu, kualitas pelayanan publik dapat diketahui dengan cara membandingkan pendapat atau persepsi masyarakat atas pelayanan yang sesungguhnya mereka inginkan. Apabila pelayanan dan praktiknya bias diterima oleh masyarakat sama dengan keinginan dan harapan mereka, maka dapat dikatakan bahwa pelanggan tersebut sudah puas. Terciptanya kepuasan pelanggan juga dapat memberikan berbagai manfaat di antaranya hubungan antara masyarakat dan pemberi layanan harmonis, reputasi instansi yang semakin baik di mata pelanggan/masyarakat. 
Berbicara mengenai kepuasan masyarakat terhadap pelayanan yang diberikan Dinas Perhubungan Kota Malang banyak laporan pengaduan perihal waktu pelayanan yang lambat. Hal ini dikarenakan banyaknya masyarakat yang sering membawa dokumen persyaratan yang tidak lengkap ataupun terdapat kendala sistem jaringan.

Namun, seiring berjalanya waktu responsivitas Dinas Perhubungan Kota Malang mengalami peningkatan yang signifikan, hal ini dibuktikan dengan adanya penurunan jumlah laporan pengaduan dari tiap bulannya pada tahun 2020. Seperti yang sudah diketahui bahwa responsivitas merupakan salah satu kriteria dalam mengukur organisasi pelayanan publik. Hal ini sesuai dengan dedikasi sumber daya manusia atau pegawai Dinas Perhubungan Kota Malang yakni harus memiliki jiwa loyalitas yang tinggi mengabdi dan bersedia bertanggung jawab atas pemerintah dan masyarakat (publik). Maka dari itu, Dinas Perhubungan Kota Malang selalu meningkatkan pelayanan dengan mengedepankan keefisienan waktu dan tanggung jawab tinggi dengan mengedepankan kepentingan publik dalam hal penanganan yang dikelola sepenuhnya oleh Dinas Perhubungan Kota Malang.

b) Kuantitas Responsivitas Pelayanan Publik Dinas Perhubungan Kota Malang Dalam Penanggung Jawaban Merespons Pengaduan Masyarakat

Berbicara mengenai sebuah kuantitas dalam hal pelayanan publik memang bersifat pelengkap dan pendukung dari sebuah kualitas. Kuantitas pelayanan adalah jumlah pelayanan yang dilaksanakan oleh seseorang pegawai dalam suatu periode tertentu (Aisha and Kurnia 2018). Kuantitas pelayanan merupakan jumlah (bisa dihitung) layanan yang dilakukan oleh birokrat kepada masyarakat dalam suatu periode tertentu (Zhang, Lihui. n.d.). Adapun kuantitas pada Dinas Perhubungan Kota Malang lebih mengutamakan pada persoalan pelayanan secara langsung kepada masyarakat baik laporan pengaduan ataupun pengajuan apa pun, pelayanan yang mengutamakan kuantitas yang di berikan oleh Dinas Perhubungan Kota Malang terlihat mengalami terus peningkatan dari segi fasilitas dan proses pelayanan kepada masyarakat. Hal ini terukur dari pihak masyarakat yang terus memberikan respons baik kepada Dinas Perhubungan Kota Malang ini.

Seperti pada Tabel 1, Laporan Jumlah Pengaduan Masyarakat Tahun 2020 dapat dikatakan cukup tinggi, namun jika dilihat lagi selama tahun tersebut terdapat penurunan kuantitas yang signifikan pada setiap bulannya. Pada data keluhan yang diterima instansi menunjukkan bahwa terdapat peningkatan responsivitas Dinas Perhubungan Kota Malang dan sudah ada penindaklanjutan terhadap keluhan masyarakat. Bentuk responsivitas Dinas Perhubungan Kota Malang yakni dengan memaksimalkan tugas bagian informasi dalam penyebaran informasi pelayanan secara akurat. Maka dari itu dapat dikatakan bahwa kualitas dari pelayanan Dinas Perhubungan Kota Malang dalam pertanggungjawaban merespons pengaduan masyarakat terdapat peningkatan kualitas pelayanan yang cukup baik sehingga membuat kuantitas atau jumlah masyarakat yang mengadu setiap bulannya semakin berkurang.

c) Prosedur Pelayanan Publik Dinas Perhubungan Kota Malang Dalam Penanggung Jawaban Merespons Pengaduan Masyarakat

Menurut Santoso dan Suwitri ( 2018) bahwa dijelaskan juga pada manajemen pengaduan masyarakat memiliki standar pelayanan yang mencangkup bagian yang bertugas menampung, mencatat, dan mengklarifikasi, dan lain sebagainya, itu semua merupakan tindakan-tindakan proses dan selalu berusaha transparan akan pengolahan data pengaduan tersebut. 
Pelayanan yang di berikan oleh Dinas Perhubungan Kota Malang semua mengarah pada prosedur dan visi misi Dinas Perhubungan Kota Malang dan mengarah pada Peraturan Walikota Malang Nomor 19 Tahun 2010 Tentang Penyelenggaraan Pelayanan Penanganan Pengaduan Di Lingkungan Pemerintah Kota Malang. Pada pelayanan pengaduan lebih fokusnya melayani publik/masyarakat dengan tanggung jawab dan loyalitas tinggi sehingga masyarakat akan bisa melakukan pengaduan sepenuhnya meliputi infrastruktur jalan ataupun fasilitas umum jalan raya langsung datang ke kantor Dinas Perhubungan Kota Malang atau melalui online sosial media yang telah di sediakan.

Berdasarkan dari tuntutan dan keluhan dari masyarakat, Dinas Perhubungan Kota Malang selalu mencoba untuk memberikan solusi atau memperbaiki kinerja dari pemberi layanan tersebut. Dinas Perhubungan Kota Malang juga selalu mensosialisasikan kepada masyarakat bagaimana cara atau prosedur melakukan laporan pengaduan. Hal ini bertujuan agar staf pelayanan Dinas Perhubungan Kota Malang tidak mengalami kendala atau kesulitan dan pelayanan masyarakat lebih terarah dan efisien. Prosedur penyelesaian pelayanan pengaduan yang diadukan oleh masyarakat bias dengan dua cara yakni melalui pengaduan secara langsung dan pengaduan secara online website, media sosial dan SMS.

Proses pengolahan dan prosedur penanggungjawaban dalam merespons pengaduan masyarakat pada Dinas Perhubungan Kota Malang:

1. Disposisi Pelaporan

Disposisi yang di digunakan untuk mencatat semua dasar pelaporan tingkat awal, Disposisi yang di teruskan pada bidang meliputi: sekretaris, kepala bidang lalu lintas, kepala bidang angkutan, kepala bidang manajemen keparkiran, kepala UPT bidang sarana prasarana.

2. Pembukuan Besar Surat pengaduan

Di sini pencatatan dari mana asal dan pelaporan dan pengajuan yang sudah tertulis pada lembar disposisi yang sudah disetujui oleh pihak bidang pelayanan baik itu dari pihak pelapor dan pengajuan dari sebuah instansi maupun publik/masyarakat yang butuh tindakan resmi pada Dinas Perhubungan Kota Malang ini. Perihal surat yang nantinya dicatat dan dimasukkan di buku besar adalah perihal di mana pelaporan yang sudah jelas dan sudah dapat di pertanggung jawabkan akan penindak lanjuti pada pemrosesan data oleh pihak staf pelayanan sebelumnya. Kemudian terdapat status pengamanan yakni di mana setelah pemrosesan terjadi dari surat disposisi yang telah disetujui oleh pihak kepala maupun sekretaris Dinas Perhubungan Kota Malang turun, dan diteruskan pada bidang yang terkait akan dicatat kembali status penindak lanjuti dan selanjutnya penanganan lapangan.

3. Penanganan Pemrosesan Data Pada Bidang Terkait

Penanganan pada bidang yang terkait dengan kesesuaian pada pelapor yang berhubungan dengan pengaduan atau pelaporan yang sudah disetujui penindak lanjutan oleh kepala maupun sekretaris Dinas Perhubungan Kota Malang, yaitu pemrosesan data terlebih dahulu yang nantinya diketahui dan apa yang harus dievaluasi atas pelaporan/pengaduan tersebut diajukan. Pemrosesan data yang dilakukan oleh bidang yang sudah diamanatkan oleh Kepala maupun sekretaris Dinas Perhubungan Kota Malang, akan diproses sesuai data pelaporan yang diajukan dan selanjutnya penanganan penelusuran data yang bermasalah apa bila di temukan yang sesuai dengan data pelaporan tersebut. Penanganan data yang akan dipersiapkan untuk digunakan penanganan lapangan akan dikaji kembali agar nantinya bisa 
dipertanggung jawabkan apa yang sudah di proses pada bidang tersebut, sehingga akan digunakan juga menjadi evaluasi penanganan pada bidang tersebut selama pemrosesan dan penanganan lapangan tersebut.

4. Penanganan Lapangan

Pelaporan penanganan lapangan yang sudah diproses oleh pihak bidang terkait dan telah disetujui oleh kepala bagian terkait selanjutnya penindakan pemantauan langsung pada lapangan dan mencari data dokumentasi foto, guna untuk di jadikan laporan awal lapangan yang selanjutnya akan dikaji ulang apakah sudah sesuai permasalahan yang diajukan oleh pihak pelapor. Penanganan pelaporan setelah dikaji ulang dan pelaporan sudah sesuai apa yang diharapkan akan diproses lanjut untuk penindakan perbaikan dan memberi perintah pada staf lapangan untuk memberi jalan keluar atas pelaporan/pengaduan tersebut, dengan sesuai standar penanganan lapangan yang sudah diterapkan pada Dinas Perhubungan Kota Malang. Para staf lapangan akan menjadikan evaluasi juga atas tindakan di lapangan yang nantinya berujung agar tidak terulang lagi dengan kejadian sama sehingga tidak digunakan pelaporan yang disalahgunakan yang mengatasnamakan seputar penggunaan fasilitas umum atau sarana prasarana umum Dinas Perhubungan Kota malang. Evaluasi yang diterapkan pada setiap bidang pelayanan Dinas Perhubungan Kota Malang yaitu penggunaan data awal yang valid sesuai pelaporan/pengaduan dan dokumentasi foto progres selama penanganan yang sudah dikerjakan sesuai standar penanganan, Yang nantinya akan dievaluasi kerja dan para staf Dinas Perhubungan Kota Malang dalam melakukan pekerjaannya agar tidak terulang lagi atas pelaporan dengan masalah yang sama disektor fasilitas dan sarana prasarana umum.

5. Pelaporan/Pengaduan dengan Sosial Media

Perkembangan teknologi yang dibarengi dengan inovasi pelayanan publik di ranah pemerintahan tentunya menuntut setiap instansi untuk mengikuti arus tersebut (Hamrun et al. 2020). Untuk mengatasi masalah ini, beberapa pemerintah secara aktif mendorong administrasi mereka untuk memberikan layanan publik secara eksklusif melalui saluran digital (Tangi, Luca. 2021). Penggunaan sosial media yang menjadi tren atau paling banyak digunakan pada dunia maya terlebih khususnya aplikasi Instagram yang digunakan Dinas Perhubungan Kota Malang untuk selalu update data terbaru atau berita terbaru dan kinerja yang sudah ditangani meliputi pelaporan dan pengaduan masyarakat, sehingga masyarakat yang mengikuti akun Instagram Dinas Perhubungan Kota Malang akan selalu memperoleh berita upload terbaru dari pihak Dinas Perhubungan Kota Malang. Sedangkan untuk pelaporan pengaduan masyarakat dapat melaporkan keluhan melalui direct message.

Dinas Perhubungan Kota Malang melakukan terobosan melalui sosial media ini guna mempermudah masyarakat/publik dapat berkomunikasi secara langsung dengan pihak administrasi pelayanan bidang publikasi, baik itu seputar permintaan informasi yang terperinci maupun pelaporan atau pengaduan yang bersifat sementara dan lain sebagainya. Hal ini terlihat karena masyarakat mulai banyak menggunakan sosial media Instagram sebagai bahan pencarian informasi bergambar maupun berupa video sehingga ini menjadi sebuah terobosan untuk inovasi bidang pelayanan untuk melayani masyarakat/publik Di Kota Malang, melalui pesan direct message tersebut juga di harapkan masyarakat akan lebih mudah melaporkan hal-hal yang bersifat informasi seputar Kota Malang sehingga Dinas Perhubungan Kota Malang akan 
selalu memantau secara up to date baik itu berita pengaduan ataupun pelaporan mengenai lalu lintas ataupun fasilitas lalulintas sarana prasarana di Kota Malang ini.

Pelaporan atau pengaduan melalui direct message tidak serta merta langsung di proses. Namun, pada bentuk laporan ini dibutuhkan data yang valid untuk dilanjutkan dalam tahap penanganan. Jika terdapat laporan yang bersifat serius, pihak pelapor akan di hubungi kembali secara personal oleh instansi untuk melapor secara formal ke kantor Dinas Perhubungan Kota Malang. Jadi bentuk laporan secara online atau melalui pesan sosial media Instagram/direct message juga dapat di pertanggung jawabkan secara utuh.

\section{Hambatan Pada Pelayanan Publik Dinas Perhubungan Kota Malang Dalam Penanggung Jawaban Merespons Pengaduan Masyarakat}

Hambatan merupakan hal yang lumrah di temukan pada setiap pekerjaan sehingga perlu pematangan tindakan serius. Hambatan yang dihadapi dalam pelaksanaan pelayanan di Dinas Perhubungan Kota Malang di antaranya sebagai berikut:

a. Kurangnya Informasi Kepada Masyarakat

Hambatan ini sering terjadi pada saat tahap awal pelayanan yakni adanya data yang belum lengkap karena kurangnya dari segi informasi dari Dinas Perhubungan Kota Malang kepada masyarakat, kurangnya informasi dipihak pelapor atau pengaduan hal ini bisa menyebabkan kesalahan fatal karena sudah menjalar ke ranah miskomunikasi dan tidak bisa dipertanggungjawabkan. Maka dari itu, pihak Dinas Perhubungan Kota Malang hendaknya meningkatkan dalam hal sosialisasi pada masyarakat, dikarenakan jika tidak disosialisasikan ke masyarakat tentunya akan berdampak pada tingkat kesadaran masyarakat yang rendah dalam hal pengurusan dokumen kependudukan.

Untuk menyampaikan pesan kepada masyarakat tidaklah mudah, pesan yang disampaikan tidak akan selalu efektif terkadang ada juga terjadi miskomunikasi, oleh karena itu sebuah pesan dapat dikemas dengan baik menggunakan model-model komunikasi (', Harto, and Handoko 2019). Selain itu Siagan (2018) berpendapat yang sama bahwa seluruh hubungan, baik itu formal dan informal perlu adanya pembentukan binaan dalam suatu organisasi aparatur guna menciptakan teamwork yang intim dan harmonis dalam segi komunikasi sehingga akan terbiasa komunikasi dengan baik kepada siapa pun dan dengan mudah menjadi kebiasaan sehingga tercapai apa yang dituju dalam pekerjaan di sebuah aparatur atau substansi terebut. Selain itu, Dinas Perhubungan Kota Malang sudah menyediakan beragam media bagi masyarakat untuk menjangkau aparatur dalam menyampaikan keluhan. Beragam media yang dapat dijangkau masyarakat ialah email, website, sms, dan Instagram.

b. Kurangnya Kesadaran Masyarakat

Maksud dari kesadaran masyarakat yang masih kurang ialah masyarakat sering membawa berkas syarat laporan pengaduan yang kurang lengkap. Maka dari itu, dari hasil evaluasi ditemukan bahwa kendala atau kesulitan yang sering dialami oleh Dinas Perhubungan Kota Malang pada pelayanan merespons pengaduan masyarakat yakni banyaknya data yang kurang akurat dari segi pelapor dan pengaduan. Sehingga penanganan dilakukan oleh Dinas Perhubungan Kota Malang adalah dengan melakukan perekapan pengaduan maupun pelaporan yang tidak beralasan jelas ataupun memang sudah ditangani sebelumnya. Maka dari itu, kurangnya kesadaran masyarakat berhubungan langsung dengan kurangnya informasi kepada masyarakat, sehingga dalam hal ini diperlukan cara berkomunikasi dari aparatur agar mudah diterima atau dipahami oleh masyarakat. 
Nakhoda: Jurnal IImu Pemerintahan

Vol. 20 No. 01 Tahun 2021 Halaman 93-105

e-ISSN: 2656-5277 | p-ISSN: 1829-5827

c. Keterlambatan Waktu Penanganan

Adapun hambatan pelayanan publik pada Dinas Perhubungan Kota Malang dalam penanggungjawaban merespons pengaduan masyarakat ialah beberapa masyarakat menilai waktu pelayanan hingga penanganan keluhan cukup lambat. Hal ini disebabkan adanya masyarakat yang sering tidak membawa berkas persyaratan yang lengkap, sehingga hal ini berdampak juga pada lama waktu penanganan pengaduan. Untuk mengatasi hal tersebut, Dinas Perhubungan Kota Malang melakukan tindakan agar semua pelayanan tidak terjadi penundaan baik pemrosesan data maupun data yang belum lengkap secara administratif. Oleh sebab itu Dinas Perhubungan Kota Malang lebih menekankan pada tahap awal pelayanan yakni dengan memperhatikan data yang di ajukan pelapor sudah cukup akurat atau tidak, sehingga dengan adanya tindakan tersebut diharapkan waktu pelayanan hingga proses penanganan lebih efisien.

Persoalan efisiensi waktu khususnya dalam pelayanan penanganan pengaduan masyarakat, Dinas Perhubungan Kota Malang selalu melakukan evaluasi terhadap kesigapan organisasi staf dalam melayani keluhan masyarakat, sikap aparatur dalam memberikan pelayanan apakah sudah sesuai dengan keinginan masyarakat, dan kesediaan aparatur untuk memberikan serta memudahkan pelayanan masyarakat. Selain itu, Dinas Perhubungan Kota Malang juga selalu mengevaluasi kinerjanya dengan tuntutan hingga kritik dari masyarakat yang diberikan kepada penyedia.

\section{Kesimpulan}

Responsivitas pelayanan publik Dinas Perhubungan Kota Malang terhadap tingginya tingkat pengaduan masyarakat dapat dikatakan sudah cukup baik. Hal ini dapat dilihat dari banyaknya jumlah laporan pengaduan masyarakat tahun 2020 terdapat penurunan yang signifikan setiap bulannya. Selain itu, hal ini dapat dilihat dari peningkatan pelayanan publik dari segi kualitasnya yang diukur dari 5 dimensi. Pertama, Tangible atau bukti fisik terkait dengan sarana dan prasarana sudah memadai dan membantu proses pelayanan. Kedua, Reliability atau keandalan yakni Dinas Perhubungan Kota Malang telah melakukan pelayanan kepada masyarakat sesuai dengan SOP. Ketiga, Responsiveness atau daya tanggap sudah cukup baik, hal ini Dinas Perhubungan Kota Malang menerapkan atau memiliki dasar pelayanan yaitu excellent service (pelayanan prima) yang bertujuan untuk berkemampuan totalitas terhadap publik yang mengajukan pengaduan dan guna memberikan respons yang baik kepada publik. Keempat, Assurance (jaminan) yakni Dinas Perhubungan Kota Malang telah memberikan jaminan kemudahan layanan dan jaminan keamanan kepada masyarakat yang mengajukan permohonan layanan. Kelima, Empathy (empati) yakni Dinas Perhubungan Kota Malang bersikap terbuka dam menerima permintaan, saran dan kritik yang diberikan oleh masyarakat.

Di samping itu, prosedur pelayanan Dinas Perhubungan Kota Malang dalam mempertanggungjawabkan merespons atas pelaporan dan pengaduan dapat dikatakan sudah sesuai dengan prosedur dan visi misi instansi. Proses pengolahan dan prosedur penanggungjawaban dalam merespons pengaduan masyarakat pada Dinas Perhubungan Kota Malang di antaranya: pertama, disposisi laporan untuk mencatatkan semua dasar pelaporan tingkat awal. Kedua, pembukuan besar surat pengaduan yakni pemrosesan data dari proses disposisi. Ketiga, Penanganan pemrosesan data pada bidang terkait yakni proses penyesuaian data dengan keadaan di lapangan. Keempat, penanganan lapangan yakni penindakan atau pemantauan langsung terhadap laporan yang sudah diproses dan disetujui oleh kepala bagian.

Hal ini juga diiringi dengan adanya hambatan-hambatan pada implementasi pelayanan publik tersebut di antaranya: pertama, kurangnya informasi kepada masyarakat perihal syarat atau prosedur pengajuan laporan pengaduan ke Dinas Perhubungan Kota Malang. Kedua Kurangnya kesadaran masyarakat dalam hal prosedur mengajukan laporan pengaduan. Ketiga, 
Nakhoda: Jurnal IImu Pemerintahan

Vol. 20 No. 01 Tahun 2021 Halaman 93-105

e-ISSN: 2656-5277 | p-ISSN: 1829-5827

keterlambatan waktu penanganan yang dikarenakan masyarakat sering membawa berkas syarat dan data laporan pengaduan yang kurang lengkap. Maka dari itu, Dinas Perhubungan Kota Malang pun mengatasi hal tersebut dengan meningkatkan kinerja staf, lebih mengemas model komunikasi agar berkurangnya tingkat komunikasi, dan sering mengadakan evaluasi.

Adapun saran bagi penyedia pelayanan publik atau aparat pemerintah khususnya Dinas Perhubungan Kota Malang yakni melakukan sosialisasi kepada masyarakat perihal bagaimana cara atau prosedur melakukan laporan pengaduan. Selain itu, Dinas Perhubungan Kota Malang selalu melakukan evaluasi dan meningkatkan kinerja sebagai penyedia pelayanan publik dan menjadikan hambatan-hambatan tersebut sebagai tantangan untuk lebih profesional dalam bertanggung jawab atas pelaporan masyarakat sehingga masyarakat merasa puas terhadap pelayanan yang diberikan.

\section{Ucapan Terima Kasih}

Peneliti mengucapkan banyak terima kasih kepada pihak-pihak terkait yakni Bapak Yaqub Cikusin, Bapak Hayat, dan seluruh Staf Dinas Perhubungan Kota Malang sebagai informan penelitian yang telah bersedia membantu dalam pengumpulan data. Ungkapan terima kasih sebesar-besarnya disampaikan pula kepada jurusan Ilmu Administrasi Publik FIA Universitas Islam Malang.

\section{Daftar Pustaka}

' Ismandianto, Syafri Harto, and Tito Handoko. 2019. "Model Komunikasi Pemerintahan Kota Tanjung Pinang Dalam Pengembangan Wisata Pulau Penyengat Kepulauan Riau.” Nakhoda: Jurnal Ilmu Pemerintahan 18(31):21-34. doi: 10.35967/jipn.v18i31.7803.

' Suherry, Billy Jenawi, Rendra Setyadiharja, Zamzami A Karim, Firman Setyawan, and Rany Angraini. 2020. "SURVEY KEPUASAN MASYARAKAT (SKM) PADA BADAN PENDAPATAN DAERAH KABUPATEN BINTAN." Nakhoda: Jurnal Ilmu Pemerintahan 19(1):102. doi: 10.35967/jipn.v19i1.7849.

Aisha, Novi, and Efri Kurnia. 2018. "Pengaruh Kuantitas Pelayanan Dan Kualitas Pelayanan Terhadap Citra Merek Pada Universitas Muhammadiyah Sumatera Utara." Jurnal Samudra Ekonomi Dan Bisnis 9(2):128-37. doi: 10.33059/jseb.v9i2.761.

Rochmah. n.d. "Manajemen Publik - Google Books." Retrieved June 26, 2021a (https://www.google.co.id/books/edition/Manajemen_publik/kWGVXrjpcjQC?hl=id\&gbpv $=1 \& \mathrm{dq}=$ responsivitas \&pg=PA177\&printsec=frontcover).

Tangisilan. n.d. "Responsivitas Pelayanan - Google Books." Retrieved June 26, 2021b (https://www.google.co.id/books/edition/Responsivitas_Pelayanan/J6ZjDwAAQBAJ?hl=id $\& \mathrm{gbpv}=1 \& \mathrm{dq}=$ responsivitas $\& \mathrm{pg}=\mathrm{PA} 1 \&$ printsec $=$ frontcover. $)$.

Asrida, Wan. 2018. "PELAYANAN PUBLIK DI FAKULTAS ILMU SOSIAL DAN ILMU POLITIK TAHUN 2015-2016.” Nakhoda: Jurnal Ilmu Pemerintahan 16(1):54. doi: 10.35967/jipn.v16i1.5796.

Chowdhury, Soumitra., Dkk. 2021. "Service Innovation in Digitalized Product Platforms: An Illustration of the Implications of Generativity on Remote Diagnostics of Public Transport Buses." Science Direct volume 65(Issue 101589):1-10. doi: https://doi.org/10.1016/j.techsoc.2021.101589.

Ghazzawi, Amani., Alharbi, Basma. 2019. "Analysis of Customer Complaints Data Using Data Mining Techniques.” Science Direct 163 (2019):62-69. doi: https://doi.org/10.1016/j.procs.2019.12.087.

Hamrun, Hamrun, Ahmad Harakan, Andi Luhur Prianto, and Nur Khaerah. 2020. "Strategi Pemerintah Daerah Dalam Pengembangan Pelayanan Berbasis E-Government Di Kabupaten Muna.” Nakhoda: Jurnal Ilmu Pemerintahan 18(2):64. doi: 10.35967/jipn.v18i2.7808. 
Nakhoda: Jurnal Ilmu Pemerintahan

Vol. 20 No. 01 Tahun 2021 Halaman 93-105

e-ISSN: 2656-5277 | p-ISSN: 1829-5827

Hayat, and Dkk. 2018. "Reformasi Kebijakan Publik: Perspektif Makro Dan Mikro.” P. 344 in Prenadamedia Group, edited by Hayat.

Hayat, Hayat. 2017. "Peneguhan Reformasi Birokrasi Melalui Penilaian Kinerja Pelayanan Publik.” Jurnal Ilmu Sosial Dan Ilmu Politik 20(2):175. doi: 10.22146/jsp.24804.

Hayat, Hayat. n.d. "Kebijakan Publik."

Kholmia, Masiyah., Dkk. 2015. "Phenomenology Study: Accountability of a Political Party in TheContext of Local Election." Science Direct 211:731-37. doi:

https://doi.org/10.1016/j.sbspro.2015.11.094.

Larasati, Widya. 2016. "PENANGANAN PENGADUAN MASYARAKAT SEBAGAI PENDUKUNG IKLIM ORGANISASI (Studi Deskriptif Kualitatif Penanganan Pengaduan Masyarakat Di Seksi Informasi Dan Sarana Komunikasi Kantor Imigrasi Kelas I Y Ogyakarta).” Profetik: Jurnal Komunikasi 9(1). doi: 10.14421/pjk.v9i1.1193.

Lopez, Liz., Fontaine, Guillaume. 2019. "How Transparency Improves Public Accountability: The Extractive Industries Transparency Initiative in Mexicostar." Science Direct Volume 6(Issue 4):1156-67. doi: https://doi.org/10.1016/j.exis.2019.09.008.

Ma, Junhai, and Chunyong Ma. 2011. "Factor Analysis Based on the COSO Framework and the Goverment Audit Performance of Control Theory." Pp. 5584-89 in Procedia Engineering. Vol. 15. Elsevier.

Mursalim, Siti Widharetno. 2018. "Analisis Manajemen Pengaduan Sistem Layanan Sistem Aspirasi Pengaduan Online Rakyat (LAPOR) Di Kota Bandung." Jurnal Ilmu Administrasi: Media Pengembangan Ilmu Dan Praktek Administrasi 15(1):1-17. doi: 10.31113/jia.v15i1.128.

Prasetya, Dimas Ramdhana. 2013. "Analisis Pengelolaan Pengaduan Masyarakat Dalam Rangka Pelayanan Publik (Studi Pada Dinas Komunikasi Dan Informatika Kota Malang).” Jurnal Administrasi Publik (JAP) 2(1):1151-58.

Riyanda. n.d. "Faktor-Faktor Yang Menghambat Kinerja Pelayanan Publik Di Dinas Kependudukan Dan Pencatatan Sipil Kota Batam - Neliti.” Retrieved June 26, 2021 (https://www.neliti.com/id/publications/114707/faktor-faktor-yang-menghambat-kinerjapelayanan-publik-di-dinas-kependudukan-dan).

Santoso, Cuher, and Sri Suwitri. 2018. "Manajemen Pengaduan Masyarakat Di Pusat Pengelolaan Pengaduan Masyarakat (P3M) Kota Semarang." Journal of Public Policy and Management Review 7.

Sari, Musfita Armala, Nur Aini, Akbar Islami, and Rury Febrina. 2019. "Aktualisasi Pertanggungjawaban Penggunaan Dana Desa Di Kabupaten Siak Tahun 2017.” Nakhoda: Jurnal Ilmu Pemerintahan 18(31):47-53. doi: 10.35967/jipn.v18i31.7805.

Siagan. 2018. Filsafat Ilmu Administrasi. Jakarta: PT. Bumi Aksara.

Suheli, Udan., Kahara, Fakhri., Kasmawati, Andi. 2015. "Public Social Services At Panti Sosial Tresna Werdha 'Gau Mabaji', District of Gowa, Province of South Sulawesi, Indonesia." Science Direct Volume 211:390-98. doi: https://doi.org/10.1016/j.sbspro.2015.11.051.

Suryotrisongko, Hatma., Jayanto, Dedy Puji., Tjahyanto Aris. 2017. "Design and Development of Backend Application for Public Complaint Systems Using Microservice Spring Boot." Science Direct 124:736-43. doi: https://doi.org/10.1016/j.procs.2017.12.212.

Tangi, Luca., Dkk. 2021. "Mandatory Provisioning of Digital Public Services as a Feasible Service Delivery Strategy: Evidence from Italian Local Governments.” Science Direct Volume 38(Issue 1):1-11. doi: https://doi.org/10.1016/j.giq.2020.101543.

Wulandari, Dewi, Alimuddin Unde, and Jeanny M. Fatima. 2017. "Kemampuan Adaptasi Dan Integrasi Pedagang Jawa Dengan Pedagang Lokal Pasar Traditional Di Kota Makassar." Jurnal Analisis 6(1):65-71.

Yandra, Alexsander. 2017. "Partisipasi Masyarakat dalam Penyusunan Rencana Pembangunan Jangka Menengah Daerah (RPJMD) Kota Pekanbaru 2012-2017.” doi: 
Nakhoda: Jurnal Ilmu Pemerintahan

Vol. 20 No. 01 Tahun 2021 Halaman 93-105

e-ISSN: 2656-5277 | p-ISSN: 1829-5827

10.31227/osf.io/aehfu.

Yurniwati., Rizaldi, Afdhal. 2015. "Control Environment Analysis at Government Internal Control System: Indonesia Case.” Science Direct Volume 211:844-50. doi: https://doi.org/10.1016/j.sbspro.2015.11.111.

Zhang, Lihui., Dkk. n.d. "A Multi-Criteria Decision Method for Performance Evaluation of Public Charging Service Quality.” Science Direct Volume 195(Issue 4). doi: https://doi.org/10.1016/j.energy.2020.116958. 